\title{
Quantitative Determination of Reducing Sugars, Oligosaccharides, and Glycoproteins with $\left[{ }^{3} \mathrm{H}\right]$ Borohydride
}

\author{
C. MoLEAN, D. A. WERNER, AND DAVID AMINOFF' \\ Departments of Internal Medicine (Simpson Memorial Institute) and Biological \\ Chemistry, the University of Michignn, Amn Arbor, Michigan 48104
}

Received December 20, 1972; accepted March 14, 1973

\begin{abstract}
A very simple and direct radioactive isotope method has been doscribed for the quantitative determination of reducing sugars. The method can be adapted to give any degree of sensitivity desired. The procedure is of general applicability to the determination of a large class of sugars. The stoichiometry of the reaction makes it a comprehensive procedure which greatly facilitates the analysis of sugars, oligosaccharides, and glycoproteins after acid and enzymic hydrolysis. Examples of the versatility of the method are given.
\end{abstract}

In our studies on glycoproteins, we have constantly searched for analytical procedures by which on sugar could be determined in the presence of others (1). There is a need for a better general analytical method that would be both applicable to all reducing sugars, oligosaccharides, and glycoproteins and, at the same time, be sensitive enough to be used on a microscale.

Borohydride reduces carbonyl compounds including aldoses and hetoses. This reaction is in general stoichiometric and therefore potentially useful as an analytical procedure. Attempts by Skell and Christ. (2) and Terenteve (3) employed borohydride in the quantitation of sugars. Their methods depended upon the reduction of sugar with excess borohydride and the determination of the excess unreacted borohydride by the manometric measurement of the hydrogen released upon aridification. The determination of the excess borohydride, by its quantitative reduction of $\mathrm{NAD}^{+}$to NADH, has enabled us to develop a spcctrophotometric method for the determination of sugars (4).?

Since a large excess of borohydride is necessary for the quantitative

${ }^{3}$ This work was supported by Grant $\mathrm{N}_{0}$. AM 07305 from the National Institutes of Health.

${ }^{2}$ Werner, D. A., Huang, C. C., and Aminoff, David, unpublished observations. 
reduction of sugar, the borohydride consumed in reducing the sugar becomes a relatively small portion of the total borohydride present. ${ }^{2}$ Hence, both the manometric and spectrophotometric methods for the determination of reducing sugars suffer frum the limitation that they determine the unreacted exeess borohydride. The use of $\left[{ }^{3} \mathrm{H}\right]$ borohydride circumvents this problem, since the acid-stable incorporated tritium would be a direct measure of the product formed.

The potential versatility of using tritiated borohydride to reduce sugars has been recognized by a number of investigators $(5,6)$, who used it with specific objectives in mind. In this communication we demonstrate the effectiveness of ["H] $\mathrm{BH} \mathrm{H}_{+}^{-}$as a reagent for the quantitative determination of sugars, oligosaceharides and sugar residucs in glycoproteins. A preliminary report of these studies has been presented 17 ).

\section{MATERIAIS AND METHODS}

Materials. Tritium-labeled borohydride was obtained from Amersham/ Searle Corj). (Arlington Heights, IL) and New England Nuclear Corp. (Boston, MA). Table 1 summarizes the data on the different batches of $\left[{ }^{3} \mathrm{H}\right] \mathrm{BH}_{4}{ }^{-}$used in these studies. The earlier work involved the use of $\left[{ }^{3} \mathrm{H}\right] \mathrm{BH}_{4}-$ from Amersham, and, with its high "acid-stable" blank, necessitated the use of charcoal (see below). The New England Nuclear (NEN) material gave a negligible "acid-stable" blank, and many of the problems of using charcoal were thereby eliminated.

The following commercially available sugars were obtained as indicated: $N$-acetyl-D-glucosamine, D(L)-arabinose (C.P.), 2-deoxy-Dribose, D(L)-galactose (C.P.), D-glucosamine-HCl (C.P.), lartose monohydrate (C.P.), $\alpha$-molibiose (C.P.), trehalose dihydrate (C.P.), turanose

TABILE: 1

Radioactivity and "Acid-Stable" Blank of Various Batches

of Tritiated Borohydride Used

\begin{tabular}{|c|c|c|c|c|c|}
\hline \multirow[b]{2}{*}{ Souree } & \multirow[b]{2}{*}{$\begin{array}{l}\text { Com- } \\
\text { pound }\end{array}$} & \multirow[b]{2}{*}{ Bateh No. } & \multirow[b]{2}{*}{$\begin{array}{c}\text { Total } \\
\text { dpme } x \\
10^{-6}\end{array}$} & \multicolumn{2}{|c|}{ Acid stable } \\
\hline & & & & $\operatorname{dpm} x$ & $\%$ of \\
\hline Amersham & $\mathrm{NaBT}_{4}$ & TRK-45 No. 13 & 5.5 & 3.85 & 0.7 \\
\hline Amersham & $\mathrm{KBT}_{4}$ & TRK-293 No.! & 6.45 & 3.86 & 0.75 \\
\hline Amersham & $\mathrm{KBT}_{4}$ & TRK-293 No.9 & 57.92 & 48.34 & 0.83 \\
\hline Amersham & $\mathrm{KBT}_{4}$ & TRA -293 No. 7 & 10.56 & 1.44 & 0.14 \\
\hline $\begin{array}{l}\text { New Fngland } \\
\text { Nuclear }\end{array}$ & $\mathrm{NaBT}_{4}$ & N LE-T-(023 No. 702-004 & 114.14 & 0.81 & () 007 \\
\hline
\end{tabular}


(Pfanstiehl Laboratories, Inc., Waukegan, IL); D(L)-fructose (Duwe's Laboratories, Chicago, IL); sucrose analytical reagent (J. T. Baker, Phillipsburg, NJ); $\mathrm{N}$-acetylneuraminic acid (Koch-Light Laboratories, Ltd., Colcnbrook Buckinghamshire, England); d-ribose (Mann Research Laboratories, New York, NY); D(L)-mannose (Eastman Kodak Co., Rochester, NY); D-glucose-1-phosphate (Nutritional Biochemicals Corporation, Cleveland, Ohio); $N$-acetylgalactosamine, $N$-acetylmannosamine monohydrate, galactosamine-HCl, and $\mathrm{D}(\mathrm{L})$-xylose (Sigma Chemical Co., St. Louis, MO) ; L-fucose (Calbiochem, Los Angeles, CA) ; and D-glucose (Mallinckrodt, St. Louis, MO). All the sugars used for these experiments were tested for purity by paper chromatography in at least two solvent systems (see below) and, with the exception of galactose, only the pure sugars were used. They were dried over $\mathrm{P}_{2} \mathrm{O}_{5}$ to constant weight before use in the preparation of the standard solutions for analysis.

The charcoal, Darco G-60, used for the removal of "acid-stable" blank was obtained from Atlas Chemical Industries, DE. The Celite used as a filter aid in admixture with the charcoal was obtained from JohnsManville Products Corp., New York, NY. The charcoal-Celite columns were prepared as follows: $40 \mathrm{~g}$ of charcoal was stirred overnight with $400 \mathrm{ml}$ of concd $\mathrm{HCl}$, filtered through Whatman No. 542 filter paper, and washed with water until the effluent $\mathrm{pH}$ was the same as the water used for washing. Forty grams of Celite was then added in $500 \mathrm{ml}$ of water and stirred for $1 \mathrm{hr}$ on a magnetic stirrer. The mixture was filtered and washed with absolute ethanol and then stirred with $20 \%$ ethanolwater mixture. The washed product was suspended in $200-300 \mathrm{ml}$ of $20 \%$ ethanol. Small columns, $1 \mathrm{ml}$, of the uniformly-mixed suspension of charcoal-Celite were made in Pasteur pipettes.

The oligosaccharides found in milk and used for these studies were obtained from Dr. Adeline Gauhe. Preparation No. TC 150A represents the neutral oligosaccharide fraction obtained from human milk by defatting, deprotcinizing, absorbing on charcoal (batchwise), and eluting with $30 \%$ ethanol after removing lactose with $10 \%$ ethanol. This preparation still contained salts and acidic oligosaccharides, and was further purified by treatment with $\mathrm{Ba}$ and $\Lambda \mathrm{g}$ acctatcs. $\Lambda \mathrm{ftcr}$ filtration, the solution was passed through cation and anion exchange columns, and the effluent was freeze dried. This preparation was further purified in our laboratory by preparative paper chromatography in solvent A to remove the excess lactose.

The hog submaxillary glycoprotein with blood group A activity was prepared as already described (8).

A mixture of glycosidases was obtained from an extract of Clostridium perfringens and had been partially fractionated with ammonium sulfate 
(50-52\% saluration) (9). This was dialyzed against $0.9 \%$ saline to remove excess ammonium sulfate prior to use.

Methods. The material to be counted was dissolved in water, and $25 \mu 1$ of the solution added to $10 \mathrm{ml}$ of a toluene/Triton X-100 scintillation mixture (10). It was counted in the Nuclear Chicago Liquid Scintillation Counter (720 series, Des Plaines, IL).

Chromatography of sugars and oligosaceharides was performed on Whatman No. 1 paper by the descending technique and with the following solvent systems: A, 1-butanol-pyridine-water $(6: 4: 3, \mathrm{v} / \mathrm{v}) ; B$, phenol saturated with water.

The composition of the oligosaceharides and glycoproteins was also determined by the following colorimetric procedures: galactose and fueose by the anthrone proecdure (11), total fucose after a 10-min heating period (12), total sialic acid by a modification (13) of the Svennerholm procedure (14), total hexosamine by the Rondle and Morgan modification (15) of the Elson-Morgan (16) reaction.

\section{STANDARD ASAAY PROCEDURE}

Reagents. (a) $0.2 \mathrm{M}\left[{ }^{3} \mathrm{H}\right] \mathrm{KBH}_{4}$ (s) act $2.5 \mathrm{mCi} / \mathrm{mmole}$ in $0.1 \mathrm{~N} \mathrm{KOH}$; (b) 0.01 a aqueous solution of sugar to be analyzed, e.g., glucose; ici 1 s $\mathrm{HCl}$.

Procedure. In the general assay procedure for glucose, aliquots of sugar solution were made up to a final volume of 100 il with water and $50 \mu 1$ of $\left[{ }^{3} \mathrm{H}\right] \mathrm{KBH}_{4}$. The solutions were set anide at $4^{\circ} \mathrm{C}$ for $24 \mathrm{hr}$. Unracted $\left[{ }^{3} \mathrm{H}\right] \mathrm{KBH}_{4}$ was decomposed completely by the ardition of excess $\mathrm{HCl}(150 \mu \mathrm{l})$. The samples were then carefully taken to dryness in vacuo in a desiceator to avoid splattering. The dried samples were then reconstituter with $200 \mu 1$ of water and redrierl. This step was repeater one more with a further $200 \mu$ of water, and the final product was reconstituted in $100 \mu$ of water, of which $25 \mu 1$ wore taken for counting in the licuid scintillation counter. Figure 1 shows a typical calihration eurve.

The acil-stable blank obtained with some hatches of $\left[^{5} \mathrm{H}\right\rceil \mathrm{BH}_{t}^{-}$was fairly bigh and represented a large lercentage of the total counts. This was effectively eliminated by passage through a chareoal-Celite columm. as follows: Reaction mixtures were set $u p$, and aliquots of $25 \mu$ l were counted directly as before. A second aliquot of $25 \mu$ was then applied to a 1-ml column of chareoa1-Crlite mixture and eluted with $1 \mathrm{ml}$ of $20 \%$ ethanol. The eluate, containing the reduced sugar but not the acidstable reagent blank, was then dried in the seintillation vial in vacuo. The resulting material was reconstituted with 200 , of water and $10 \mathrm{ml}$ of the scintillation fluir and counter. Figure 2 shows the effectiveness of the procedure for the removal of this acid-stable blank. 


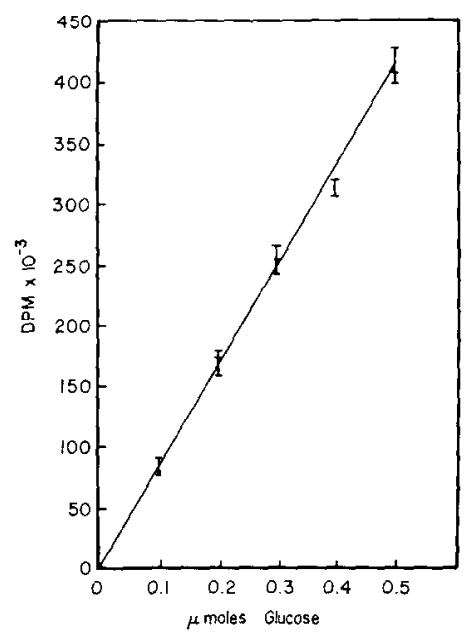

FIa. 1. Calibration curve for glucose. Glucose $(0-0.5 \mu$ mole) contained in a final volume of $50 \mu \mathrm{l}$ was incubated at $4^{\circ} \mathrm{C}$ for $24 \mathrm{hr}$ with $50 \mu \mathrm{l}$ of $0.2 \mathrm{M}\left[{ }^{3} \mathrm{H}\right] \mathrm{KBH}_{4}$ (New England Nuclear Corp.) in $0.1 \mathrm{~N} \mathrm{KOH.} \mathrm{See} \mathrm{text} \mathrm{for} \mathrm{experimental} \mathrm{conditions.}$

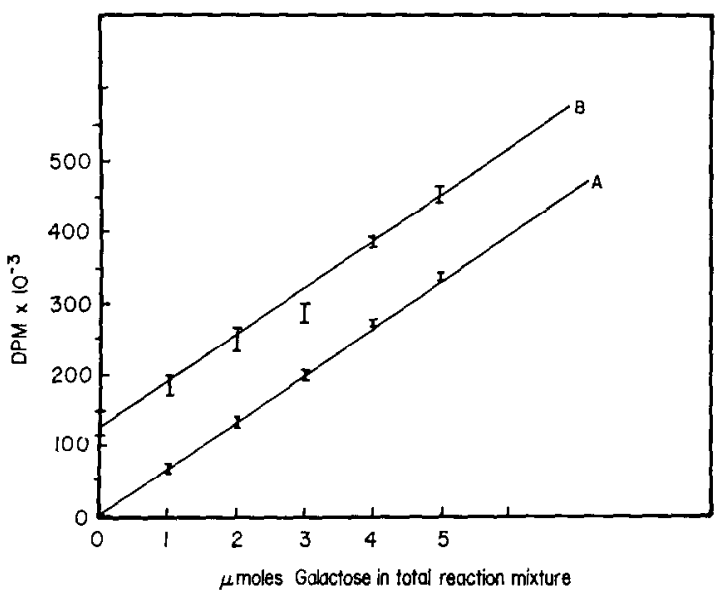

FIG. 2. Effectiveness of charcoal-Celite chromatography in the removal of the acid-stable contaminant from $\left[{ }^{3} \mathrm{H}_{3} \mathrm{BH}_{4}{ }^{-}\right.$. The reaction mixture contained ${ }^{1-5}$ $\mu$ moles of galactose and $100 \mu$ moles of $\left[{ }^{3} \mathrm{H} \mathrm{KBH}_{4}\right.$, batch TRK 293 No. 9 , in $0.1 \mathrm{~N} \mathrm{KOH}$ and in a final volume of $100 \mu \mathrm{l}$. The solutions were incubated for $24 \mathrm{hr}$ at $4^{\circ} \mathrm{C}$, and then $25 \mu$ l counted directly after treatment in the Standard Assay Procedure. A second 25- $\mu$ l aliquot from each incubation was applied to a charcoalCelite column and treated as described in the text. The appropriate corrections for quenching and efficiency of counting were applied to the two sets of readings. (A) After charcoal treatment; (B) before charcoal treatment. 


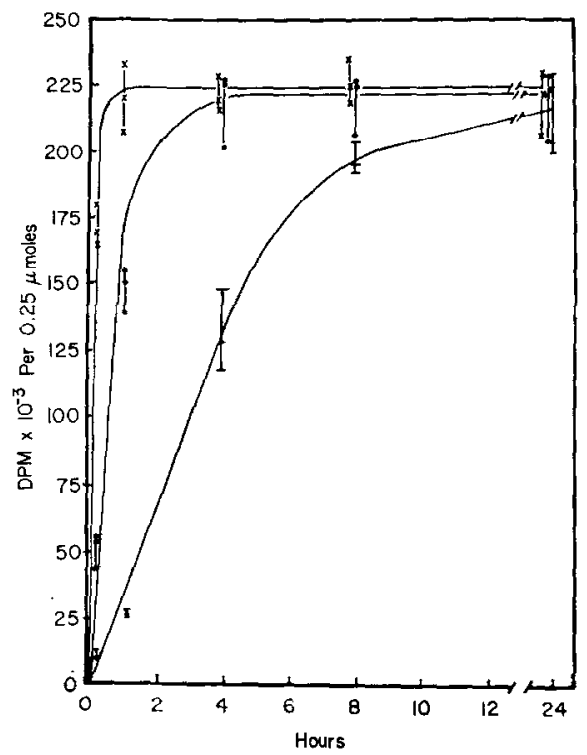

Fis. 3. Effect of temperature on the rate and extent of incorporation of tritium into glucose. Glucose $(0.25 \mu$ mole $)$ mixed with $10 \mu$ moles of $\left[{ }^{3} \mathrm{H}\right] \mathrm{KBH}_{4}$ in $100 \mu \mathrm{l}$ of solution was incubated for varying periods of time at $4^{\circ} \mathrm{C}(|-|) ; 25^{\circ} \mathrm{C}$ $(-\infty) ; 37^{\circ} \mathrm{C}(\times \longrightarrow \times)$.

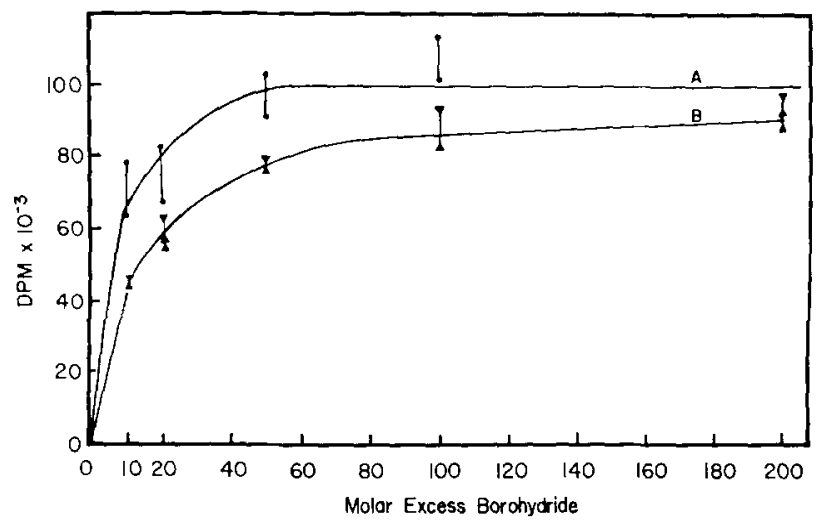

Fig. 4. Effect of excess $\left[{ }^{3} \mathrm{H}\right] \mathrm{KBH}_{4}$ on the extent of reduction of glucose at $4^{\circ} \mathrm{C}$ for $5 \mathrm{hr}$ (B) and for $48 \mathrm{hr}$ (A). The final reaction mixtures contained $0.1 \mu$ mole of glucose and varying amounts of $\left[{ }^{3} \mathrm{H}\right] \mathrm{KBH}_{4}(1,2,5,10$, or $20 \mu$ moles $)$ representing a $10-, 20-, 50-, 100-$, or 200-fold molar excess of the reducing agent, over the sugar. 


\section{Variables Affecting the Assay}

Effect of Temperature. Reaction mixtures were prepared as in the standard procedure with a constant amount of glucose, and the resulting solutions were kept at different temperatures. Figure 3 shows the results obtained.

Effect of Excess $\left[{ }^{3} \mathrm{H}\right] \mathrm{KBH}$. The effect of excess molar ratio of $\left[{ }^{3} \mathrm{H}\right] \mathrm{KBH}_{4}$ to sugar on the extent of reduction of glucose at $4^{\circ} \mathrm{C}$ for 5 and $48 \mathrm{hr}$ is shown in Fig. 4.

\section{Applications of Assay}

Reductive Equivalent of Monosaccharides and Disaccharides. Each reaction mixture contained $0.25 \mu$ moles of the sugar and $10 \mu$ moles of $\left[{ }^{3} \mathrm{H}\right] \mathrm{KBH}_{4}$ in a final volume of $100 \mu$. Reduction of the sugar occurred at $4^{\circ} \mathrm{C}$ for $24 \mathrm{hr}$. The reaction was stopped by the addition of $150 \mu \mathrm{l}$ of $1 \mathrm{v} \mathrm{HCl}$, and the samples treated as in the Standard Assay Procedure. Triplicate samples of each sugar were taken, and the extent of reduction was compared to that of glucose. Table 2 shows the results obtained. With sialic acid and the hexosamine hydrochlorides, it was necessary to assure the alkalinity of the reaction mixture by the addition of 2.5 $\mu$ moles of $0.1 \mathrm{~N} \mathrm{KOH}$ before reduction.

Purity of the Galactose Preparation. Five micromoles of galactose was reduced with $\left[{ }^{3} \mathrm{H}\right] \mathrm{KBH}_{4}$ in the usual way $\left(4^{\circ} \mathrm{C}, 24 \mathrm{hr}\right)$, and the sample acidified, washed, and subjected to ion exchange chromatography on Dowex 50 (200-400 mesh, $\mathrm{H}^{+}$form) cluted with water, concentrated, and applied to Dowex 1 (200-400 mesh, $\mathrm{OH}^{-}$form), again eluted and concentrated. Total recovery from the ion exchange resins was monitored by counting. The final concentrated eluate was applied to Whatman No. 1 paper and developed for $60 \mathrm{hr}$ in solvent $A$. Strips of the chromatogram were stained with periodate and $\mathrm{AgNO}_{3}$, and the spots visualized and compared to nonradioactive markers, galactitol, and lactitol. An unstained strip of the paper was cut into 1-in. strips, which were placed in counling vials together with $100 \mu \mathrm{l} \mathrm{H}_{2} \mathrm{O}$ and $15 \mathrm{ml}$ scintillation fluid, and counted. Radioactivity above a background of $50 \mathrm{cpm}(17 \%$ efficiency) was found only in those arcas corresponding to $2 \%$ lactitol and $98 \%$ galactitol.

Reduction of Milk Oligosaccharides. A solution containing $38 \mu$ moles/ $\mathrm{ml}$ of anthrone-positive material was prepared. Incubation mixtures containing $10 \mu \mathrm{l}$ of the milk oligosaceharide solution, $40 \mu \mathrm{l}$ of water, and $50 \mu$ of $\left[{ }^{3} \mathrm{H}\right] \mathrm{KBH}_{4}$ reagent $(0.2 \mathrm{~m}$ in $0.1 \mathrm{~N} \mathrm{KOH})$ were prepared. The reaction mixtures were maintained at $4^{\circ} \mathrm{C}$, and at predetermined intervals of time the reaction was stopned by acidification with $150 \mu \mathrm{l}$ of $1 \mathrm{~N} \mathrm{HCl}$, and the samples treated as in the Standard Assay Procedure. 
TABLE 2

The Reductive Equivalence and Standard Jeviation in the Determination of Various Redueing and Nonreducing Sugars

\begin{tabular}{|c|c|c|}
\hline Sugar & $\begin{array}{l}\text { Reducing equivalent } \\
\qquad\left(C_{0}^{\prime}\right)\end{array}$ & $S^{b}$ \\
\hline Glucose & 100 & 0.5 \\
\hline (ralactose & 91 & 5.7 \\
\hline Mannose & 98 & 6.1 \\
\hline Fructose & 1114 & 9.3 \\
\hline Fucose & 106 & 5.5 \\
\hline Glucuse-1-Phosphate & 0 & - \\
\hline Glucosamine-HCl & 83 & 0.7 \\
\hline Galactosamine- $\mathrm{HCl}$ & 85 & 3.7 \\
\hline$N$-Acelylgalactosamine & 92 & 3.6 \\
\hline$N$-Acetylmannosamine & $y_{2}^{2}$ & $9 . \tilde{5}$ \\
\hline$N$-Acetylneuraminic Acid & 86 & 2.5 \\
\hline Glucosamine- $\mathrm{HCl}^{a}$ & 98 & 5.9 \\
\hline Galactosamine- $\mathrm{HCl}^{a}$ & 103 & 8.3 \\
\hline$N$-Acet ylglucosamine ${ }^{\iota}$ & 92 & 0.8 \\
\hline$N$-Acetylgalactosamine ${ }^{a}$ & 91 & 2.5 \\
\hline$N$-Acetylmannosamine ${ }^{a}$ & 98 & 2.6 \\
\hline$N$-Acetylneuraminic Acid ${ }^{n}$ & 102 & 4.1 \\
\hline Arabinose & 107 & 7.4 \\
\hline Ribose & 106 & 1.1) \\
\hline $\mathrm{Xylose}$ & 109 & 2.7 \\
\hline 2-Deoxyribose & 114 & 5.2 \\
\hline 2-Deoxyglucose & 115 & 6.3 \\
\hline Lactose $\cdot \mathrm{H}_{2} \mathrm{O}$ & $11: 4$ & 6.2 \\
\hline Melibiose & 104 & 2.2 \\
\hline Turanose & 76 & 17.8 \\
\hline Trehalose & 0 & - \\
\hline Sincrose & 0 & - . \\
\hline
\end{tabular}

"These sugars were neutralized and made alkaline by the addition of $0.1 \mathrm{~N} \mathrm{KOH}$ prior to reduction with the tritiated borohydride. See text for the experimental details.

"The standard deviation was calculated for each sugar from the variance of these determinations from their mean and then expressed as a percentage of their mean.

Figure 5 shows a comparison of the rate of reduction of glueose and the milk oligosaceharides.

Rate and Extent of Hydrolysis of $A+$ Hog Submaxillary Cilycoprotein with $0.5 \mathrm{~N} \mathrm{HCl}$ at $100^{\circ} \mathrm{C}$. The hydrolysis mixture was prepared as follows: $100 \mu \mathrm{l}$ of $1 \%$ solution of the $\mathrm{A}+$ (active) hog submaxillary glycoprotein, $400 \mu \mathrm{l}$ of water, and $500 \mu \mathrm{l}$ of $1 \mathrm{~N} \mathrm{HCl}$. The well-mixed solution was then transferred to 2 -ml ampules and sealed. The ampules were placed in a refluxing water bath for predetermined intervals of time. After hydrolysis, aliquots from each ampule (run in duplicate) 


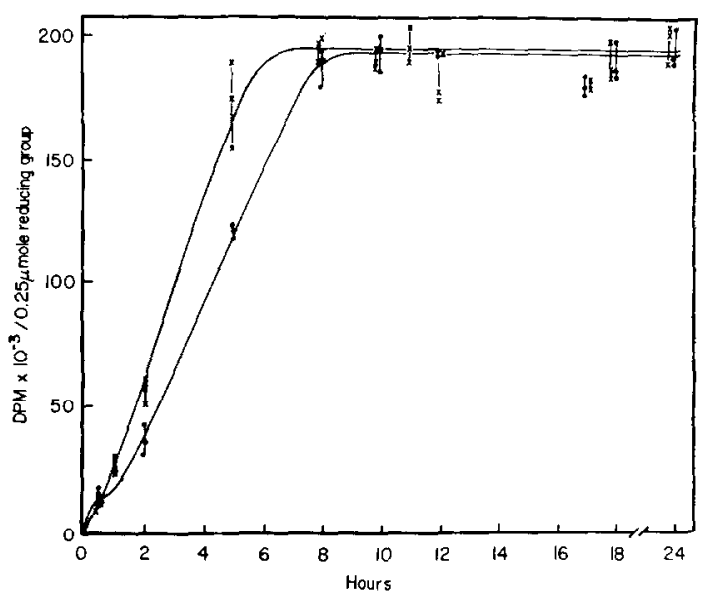

FIg. 5. The rate of reduction of $0.01 \mathrm{~m}$ glucose- $(\times-\infty)$ and lactose-free $(\mathrm{O}-\mathrm{O})$ milk oligosaccharides by $\left[{ }^{3} \mathrm{H}\right] \mathrm{KBH}_{4}(0.2 \mathrm{M})$ at $4^{\circ} \mathrm{C}$. Tubes contained $0.25 \mu$ mole glucose $(0.01 \mathrm{M})$ or $0.25 \mu$ mole reducing groups from milk oligosaccharides (calculated from a previous experiment) and $10 \mu$ mole $\left[{ }^{3} \mathrm{H}\right] \mathrm{KBH}_{4}(0.2 \mathrm{M})$ in a total volume (with water) of $100 \mu \mathrm{l}$. Reactions were stopped, and assays conducted as in the standard procedure.

were centrifuged, and $50 \mu l$ of the supernatants treated with $50 \mu l$ of $1 \mathrm{~N} \mathrm{KOH}$ to neutralize the acid and assure alkalinity of the reaction mixture. The next step involved reduction of the free sugars released with $100 \mu$ of $\left[{ }^{3} \mathrm{H}\right] \mathrm{KBH}_{4}(0.2 \mathrm{M}$ in $0.1 \mathrm{~N} \mathrm{KOH})$ at $4^{\circ} \mathrm{C}$ for $24 \mathrm{hr}$. The acid-stable radioactivity was measured in the usual manner. The rate of hydrolysis and maximum reductive equivalent is shown in Fig. 6. The

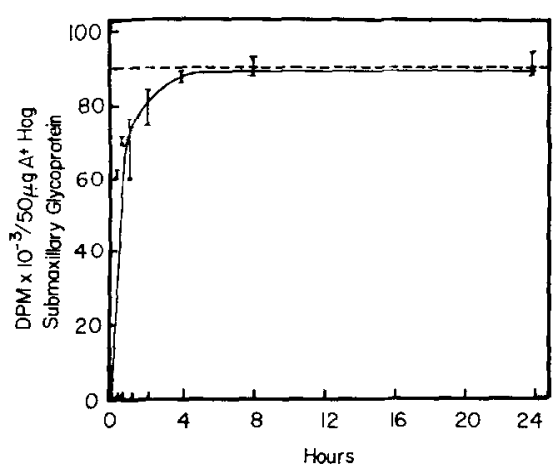

FIG. 6. Rate and extent of hydrolysis of At hog submaxillary glycoprotein with $0.5 \mathrm{~N} \mathrm{HCl}$. See text for cxperimental details. (----) The expected maximal amount of incorporation. 


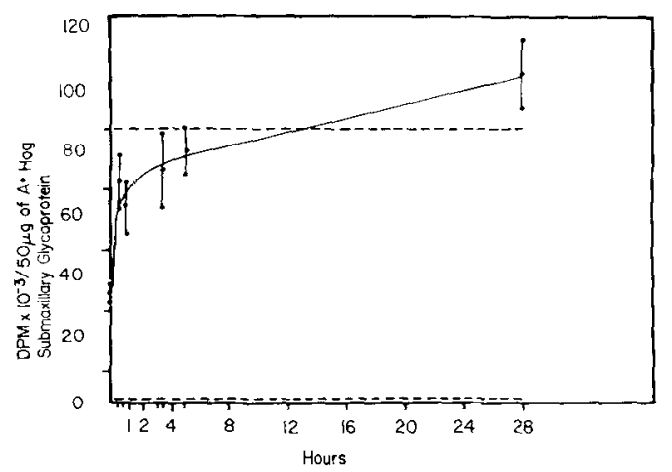

FIti. 7. Rate and extent of hydrolysis of A+ hog submaxillary glycoproteins with glycosidases. Sce text for exporimental details. (-...) The expected amount of incorporation.

expected incorporation of radioactivity is calculated from the amount of $N$-glycolylneuraminic acid, galactose, fucose, and $N$-acetylgalactosamine known to be present in the intact glycoprotein $(8)$.

Rate and Extent of Hydrolysis of A+Hog Submaxillary Glycoprotein with Glycosidases. An incubation mixture was prepared as follows: $0.25 \mathrm{ml}$ of $1 \%$ solution of A+ hog submaxillary glycoprotein, $1.75 \mathrm{ml}$ of

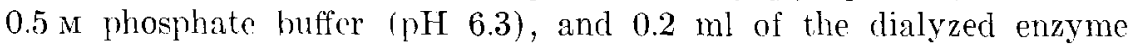
preparation of Clostridia glycosidases. The solution was incubated at $37^{\circ} \mathrm{C}$, and at predetermined time intervals $100-\mu l$ aliquots were removed, and the enzymic hydrolysis stopped by immersion for $2 \mathrm{~min}$ in a boiling water bath. Proteins were precipitated by the addition of $400 \mu l$ absolute ethanol to yield a final conecntration of $80 \%$. The solutions were centrifuged for $10 \mathrm{~min}$ at $88,000 \mathrm{~g}$, and aliquots of $200 \mu \mathrm{l}$ of the supernate eraporated to dryness in racmo, redissolved in $\mathrm{KOH}(50 \mu \mathrm{l}$ of $0.1 \mathrm{~N})$, and reduced with $\left[{ }^{3} \mathrm{H}\right] \mathrm{KBH}, 150 \mu .20 .2 \mathrm{x}$ in $\left.0.1 \mathrm{~N} \mathrm{KOH}\right)$ at $4^{\circ} \mathrm{C}$ for $24 \mathrm{hr}$. Figure 7 shows the results obtained. The data are expressed as dpm $\times 10^{3}$ incorporated per $50 \mu \mathrm{g}$ of $\mathrm{A}+$ hog submaxillary glyeoprotein to compare with the results obtained by acid hydrolysis of an efiuivalent amount of this glycoprotein. Both the enzyme blank and substrate blank were negligible.

\section{RESUILTS AND DISCUSSION}

Most of the parameters of the reaction of the sugars with horohydride had already heen determined using the NAD+ assay (4,7) (sec Footnote 2 ). These were reconfirmed using the radinactive assay procedure It was further observed ${ }^{2}$ that the rate of reduction of different sugars varies, but on completion of the reaction a simple stoichiometry was cvident. 
with most sugars having the same reductive equivalent. The notable exceptions were the acidic sugars like sialie acid, the hexosamine hydrochlorides, and $N$-acety hexosamines.

The anomalous bchavior of thesc sugars was climinated by two measures, firstly by insuring that the solution of the sugar was strongly alkaline before the addition of the $\left.{ }^{3} \mathrm{H}\right] \mathrm{BH}_{4}-$ and secondly by carrying out the incubations at $4^{\circ} \mathrm{C}$ rather than at $45^{\circ} \mathrm{C}$ (Fig. 3 ). At the higher temperatures, the hexosamines, $N$-acetylhexosamines, and sialic acids are unstable and give the chromogen precursors typical of the colorimetric tests for these sugars (16-18). At $4^{\circ} \mathrm{C}$ the amount of borohydride necessary to achieve maximal reduction of the sugar was found to be 20-50-fold molar excess (Fig. 4).

In our early studies, the $\left[{ }^{3} \mathrm{H}\right] \mathrm{BH}_{4}{ }^{-}$used was obtained from Amersham/ Searle. These preparations had an acid-stable blank of about $0.7 \%$. While normally that might be considered a low content of impurity, with a 20-50-fold molar excess of $\left[{ }^{3} \mathrm{H}\right] \mathrm{BH}_{4}$ - necessary for complete reduction of the sugars, the acid-stable blank becomes a serious problem. A number of different batches of borohydride from Amersham were used and all had a 'high' blank (Table 1). The best procedure to remove that "acidstable" blank was to pass the reaction products, after reduction with borohydride and removal of excess borohydride by acidification, through a short column of charcoal-Celite as indicated in the Mcthods section. This was effective in removing all the "acid-stable" blank to give a calibration curve that passed through the origin and which was parallel with the calibration curve without using chareoal (Fig. 2). Where a good sample of $\left[{ }^{3} \mathrm{H}\right] \mathrm{BH}_{+}{ }^{-}$was not available, a simple mathematical subtraction of the "acid-stable" blank of the borohydride could correct the error. A batch of borohydride obtained from the New England Nuclear Corp. (Table 1) had a negligible acid-stable blank, and the reagent gave a suitable calibration curve without the necessity of using charcoal (Fig. 1).

Using the Slandard Assay Procedure with the borohydride from New England Nuclear Corp., it was possible to determine the reductive equivalent of a number of monosaccharides, reducing and nonreducing disaccharides. Table 2 shows the results obtained and indicates that nonreducing disaccharides, sucrose, and trehalose and aldoses substituted at position 1 (e.g., glucose-1-phosphate) do not react with borohydride. Within experimental error, the majority of hexoses, pentoses, ketose, and methylpentose react to the same extent as glucose, used as the standard for comparison. In view of the low reducing equivalent of galactose and its contamination with lactose, as was demonstrated by paper chromatography, it was of interest to utilize the radioactive assay to determine the 
purity of the galactose. Chromatographic separation of the corresponding radioactive alditols and counting the radioactivity corresponding to galactitol and lactitol indicated a $98 \%$ purity of the galactose with $2 \%$ contamination with lactose.

The rate of reduction of complex oligosaccharides, such as those found in human milk (Fig. 5), appear to be analogous to that of the simple sugars and reducing disaccharides. Therefore, the extent of incorporation of radioactivity is directly proportional to the number of reducing groups available. Hence the method is ideally suited to the determination of rate of hydrolysis of glyeoproteins with acid or enzymes (Figs. 6 and 7 ). Morcover, as can be seen from the data obtained on mild acid hydrolysis of $\mathrm{A}+$ hog submaxillary glycoprotein, the total reductive ecpuivalent at the completion of hydrolysis corresponds to that calculated from the cuantities of individual sugars known to be present in this prejaration. This illustrates the analytical versatility of the procedure. Chromatographic separation of the components in the acid hylrolysate presents a quick method of overall analysis of the amounts of each sugar present in the glycoprotein. The advantage of this simplicity is rearlily apparent. For instance, the determination of the composition of the earbohydrate components within the glycoprotein from $\mathrm{A}+$ hog submaxillary glands required the determination of the sialie acid by the resorcinol methor $(13,14)$, galactose and fucose by the anthrone procedure (11), the fucose alone by the cysteine mothod (12), and the total hexosamine by the Elson-Morgan procedure (15,16!. The overall estimate of ach component further requires a correction factor for the rlifferent molar extinction coefficients of the sugars in the varions determinations. For example. $N$-acetylncuraminie acid was ueer as the standard in the resorcinol tent, whereas the rialic acid in hog submaxillary glycoproteins is known to be predominantly $N$-glyeolyl $(19,20)$, which give $134 \%$ of the intensity given by $N$-acetylneuraminic acid (8).

The higher maximal reductive equivalence obtained with $A+$ hog submaxillary glycoprotein after enzymic hydrolysis is due to the small amount of $N$-acetylncuraminic acid aldolase prosent in the crude $\mathrm{Cl}$. perfringens extract used. This enzyme would further elcare the $\mathrm{N}$-glycolylneuraminic acid released with the sialidase in the enzyme preparation into $N$-glycolylmannosamine and pyruvate $(9,21)$, thereby doubling the number of carbonyl groups available for reaction with the tritiated borohydride.

The analytical procedurc lends itself to any degree of sensitivity recuired depending on the amount of sugar availahle for retermination and the specific aetivity of the tritiated borohydride used. The method can, moreover, be used to determine the chain length of a given oligo- 
saccharide of known composition, or alternatively, the molecular weight of a given reducing oligosaccharide if it is known to be pure.

The applicability of the method to the analysis of other classes of compounds known to react with borohydricle is obvious, e.g., lactones and esters and the uronic acids in polysaccharides after esterification (22). The analysis of alkali-labile glycoproteins and the use of the method to give a fingerprint pattern of oligosaccharides in glycoproteins will be discussed in a subsequent publication.

\section{ACKNOWLEDGMENTS}

Our thanks to colleagues Dis. I. A. Bernstein, I. Goldstein, and G. W. Jourdian, who provided us with some of the sugars used.

\section{REFERENCWS}

1. Aminoff. D., Binkley, W. W., Schaffir, R., and Mowry, R. W. (1970) in The Carbohydrates, Chmistry and Biochemistry (Pigman, W., and Horton, D., cds.), Vol. IIB, p. 740, Academic Press, New York.

2. Skeld, P. S., and Crist. J. G. (1954) Nalure (Loulon) 173, 401.

3. Terenteve, A. P. (1965) Zh. Anal. Khim. 20, 836; Terenteve, A. P., and Novikova, I. S. (1965) Zh. Anal. Khim. 20, 1226.

4. Werner, D. A., Huang, C. C., and Aminoff, D. (1973) Anal. Biochem. in press.

5. Conrad, H. E., Bamburg, J. R., Epley, J. D., axd Kindt, T. J. (1966) Biochemistry 5, 2808.

6. Murakami, M., and WinzLer, R. J. (1967) J. Chromatogr. 28, 344.

7. Werser, D. A., Huavg, C. C., aNd Aminoff, D., International Symposium on Carbolyylrate Chemistry, VI, August 14-18, 1972, Madiron, Wisconsin.

8. Aminoff, D., and Morrow. M. P. (1970) Fed. Eur. Biochem. Soc. Letters 8, 353.

9. Amivorf, D., and Firutiwa, K. (1970) J. Biol. Chem. 245, 1659.

10. HAYm, F. N. (1963) Packard Technical Bulletin. No. 1. p. 1.

11. Dreywood, R. (1946) Ind. Eng. Chem. And. Ed. 18, 499.

12. Dische, Z., AND Sheittes, I. B. (1948) J. Biol. Chem. 175, 595.

13. Cassidy, I. T., Jourdin, G. W. ani Roseman, S. (1965) J. Biol. Chem. 240, 3501 .

14. Svennerholm, L. (1957) Biochim. Biophys. Acta 24, 604.

15. Rondt. . . .T. M., and Morgan. W. T. J. (1955) Biochem. J. 61.586.

16. Rlaon. T. A. and Mokfay. W. T. J. (1933) Biochem. J. 27, 1824.

17. Morgin. W. T. J., and Elson, L. A. (1934) Biochem. J. 28, 988.

18. AMINOFF, D. (1961) Biochem. J. 81, 384.

19. Carlson, D. M. (1968) J. Biol. Chem. 243, 616.

20. Bair, M. M., and Aminoff, D. (1972) J. Biol. Chem. 247, 6111.

21. Comb, D. G., and Rosfman, S. (1960) J. Biol. Chem. 235, 2529.

22. Taylor. R. I., and Conrad, H. E. (1972) Biochem. 11, 1383. 